\title{
Comparison of Financial Performance Buku III Indonesian Banks Using Risk-Based Bank Rating (Rbbr) Method: Case Study of PT. Pan Indonesia Bank, Tbk (Panin) and PT. Bank Mega, Tbk (Mega)
}

\author{
Wiwiek Mardawiyah Daryanto \\ Sekolah Tinggi Manajemen IPMI, DKI Jakarta 12750, Indonesia
}

\begin{abstract}
A B S T R A C T
Indonesia has experienced economic crisis in 1997/1998 and 2008, these events motivate the government to have a strong assessment to evaluate the financial health of the company. Related to the banks industry, government of Indonesia through Financial Service Authority or Otoritas Jasa Keuangan (OJK) issued the Circular Letter of OJK No. 14/SEOJK.03/2017 about Risk-Based Bank Rating (RBBR) approach that include the evaluation of risk profile, good corporate governance, earnings, and capital. The purpose of this study is to assess the financial health of the two open recorded non-expressed claimed BUKU III banks in Indonesia, which are Bank PT. Pan Indonesia Bank, Tbk (Panin) and PT. Bank Mega, Tbk (Mega) from year of 2014 to 2018. The methodology used is RBBR approach concerning the Rating of Health of Commercial Banks. The data were collected from the yearly report of the banks, fiscal reports, diaries, and articles of PT. Bank Mega and PT. Bank Panin. During the five-year trend, the result of this study reveals that the two banks have performed well. However, Bank Mega has performed better in terms of Loan to Deposit Ratio (LDR) compared to Bank Panin. This study has added the knowledge in the financial literature. It also brings benefit for managers to help them make a better decision to address their company's problem.
\end{abstract}

\section{A R T I C L E I N F O}

Article History:

Received : 26-02-2020

Revised : 01-03-2020

Accepted : 01-03-2020

Published : 02-03-2020

Keywords:

BUKU III Banks,

Risk-Based Bank Rating,

Financial Health,

Banking Industry.

*Corresponding Author E-mail:

wiwiek.daryanto@ipmi.ac.id

Copyright $₫ 2020$ Authors. This is an open access article distributed under the Creative Commons Attribution License, which permits unrestricted use, distribution, and reproduction in any medium, provided the original work is properly cited.

\section{INTRODUCTION}

The financial business has a critical influence in the improvement of a nation's monetary development rate, especially in Indonesia. A bank plays the intermediary role in the middle of surplus and deficit of the money related segment. To perform well in these exercises, the monetary 
organization needs to have a legitimate administration that is proficient in activating the bank's asset in appropriate way, a capital that is utilized as asset to render the administration, legitimate measure of revenue that will surpass the expense of activity, a legitimate framework that will shield the advantage of the business and a sufficient budgetary situation to settle claims at the hour of liquidity (Adesina, 2012).

Bank wellbeing is the capacity of banks to do banking tasks typically and have the option to satisfy commitments appropriately and in a way that is following relevant financial guidelines (Budisantoso, 2006). Economic crisis that was incurred in the year of 1997/1998 and 2008 in Indonesia gave a review of the significance of estimating the soundness of banks and the versatility framework. The crisis caused liquidity challenges due to the decrease in the conversion scale of the Rupiah against the US dollar, declined productivity of workforce, lastly capital depleted that prompted the financial business crisis around then (Chitya, 2015). The Century Bank case is one of the cases that occurred in Indonesian banking as an effect of the crisis.

The repetition of the financial crisis happened due to the fact that banks are trust establishments that are defenseless against huge withdrawals of assets by clients. Rivalry between banks in gathering assets from general society and directing it back as credit, by and by, may digress from appropriate guidelines, for example, not making a difference the judicious rule in offering credit to clients with the goal that it regularly harms investors. Thusly, Bank Indonesia, as a central bank, has a job in both the bank's wellbeing and the flexibility framework estimation. Bank Indonesia gave an arrangement to evaluate the adequacy of banks utilizing the CAMELS strategy dependent on Bank Indonesia Regulation No. $6 / 10 / 2004$ concerning the Rating of Soundness of Commercial Banks utilizing the CAMELS Method. The CAMELS technique incorporates six measurements, which are Capital, Asset, Management, Earnings, Liquidity, and Sensitivity to the Market Risk.
In 2011, Bank Indonesia gave a Circular Letter of Bank Indonesia No. 13/24/DPNP 2011 identified with guideline No. 13/1/PBI/2011, trailed by Financial Service Authority ('OJK') round in SE OJK No. 14/SEOJK.03/2017 concerning the strategy for surveying the adequacy of keeps money with a hazard approach called Risk-Based Bank Rating (RBBR). This new principle is a consummated of the CAMELS strategy that recently utilized. The improvement of the adequacy rating approach of business keeps money with the risk approach is required to energize expanded viability in the use of Risk Management and Good Corporate Governance with the point that the Bank can distinguish issues early so they can make enhancements varying all the more rapidly so later they can confront different crisis that happen. The RBBR technique evaluates parts of Risk Profile, Good Corporate Governance, Earnings, and Capital.

Bank Indonesia Regulation or Peraturan Bank Indonesia (PBI) No. 14/26/PBI/2012 dated 27 December 2012, concerning Business Activities and Office Networks Based on Bank's Core Capital expresses that dependent on center capital claimed, Banks are assembled into four business activities or called Bank Umum Kegiatan Usaha (BUKU).

Based on the core capital that owned by the banks, currently Indonesia has four categories to be assessed for:

1. BUKU I, banks with total core capital (Tier 1) less than IDR 1 Trillion.

2. BUKU II, banks with total core capital (Tier 1) between IDR 1 Trillion to less than IDR 5 Trillion.

3. BUKU III, banks with total core capital (Tier 1) between IDR 5 Trillion to less than IDR 30 Trillion; and

4. BUKU IV, banks with total core capital (Tier 1) between above IDR 30 Trillion

In 2018, twelve open recorded banks were recorded under BUKU III. Among them, there are nine exclusive banks, which are PT. Skillet Indonesia Bank, Tbk; PT. Bank Danamon Indonesia, Tbk; PT. Bank Maybank Indonesia, Tbk; PT. Bank Permata, Tbk; PT. Bank Mega, Tbk; PT. Bank 
Mayapada Internasional, Tbk; PT. Bank OCBC NISP, Tbk; PT. Bank Bukopin, Tbk, and PT. Bank Tabungan Pensiunan Nasional, Tbk.

This study investigates the financial health of the two open recorded non-expressed claimed BUKU III banks in Indonesia, which are Bank PT. Pan Indonesia Bank, Tbk (Panin) and PT. Bank Mega, Tbk (Mega) from year of 2014 to 2018 by using Risk-Based Bank Rating (RBBR) strategy in provision of the risk profile, revenue, and capital factors.

PT Bank Pan Indonesia, Tbk (hereinafter referred to as PaninBank) is one of the largest Commercial and Retail banks in Indonesia. Bank Panin was established in 1971 as a result of merger from the Bank of Prosperity, Bank Industri Jaya, and Bank Industri Dagang Indonesia. In 1972, Bank Panin obtained a license as a foreign exchange bank, ten years after, PaninBank made an initial public offering as well as being the first bank in Indonesia to register its shares on the floor stock exchange. Until year of 2018, Bank Panin has more than 560 branch offices throughout Indonesia, as well as one representative office in Singapore (Annual Report of Bank Panin, 2018).

PT. Bank Mega, Tbk (hereinafter referred to as Mega) was founded in 1969 under the name of PT. Karman bank, it was firstly commenced its commercial operations at Surabaya, East Java. In two years later, it changed its name to PT. Mega Bank and relocating its headquarter to Jakarta. Under the same year, PT. Bank Mega conducted its Initial Public Offering and listed on the JSX and BES. MEGA. Bank Mega offers the products namely Mega Dana, Mega Taxi, Mega Proteksi for its saving accounts; Mega Pro and Mega Business for its Current Account; Mega Depo, Mega Deposito On Call and Mega Sertifikat for its Term Deposits (Annual Report of Bank Mega, 2018).

\section{LITERATURE REVIEW}

The concept of Financial ratio has been used to measure the performance in various industry, namely oil and gas (Daryanto and Nurfadilah, 2018), banking (Daryanto and Arrifa'I, 2019;
Fannywaty and Daryanto, 2019; Pinto et al., 2017), and others.

Previos study conducted by Hawaldar et al., (2017) examined the financial performance of banks after the oil price crisis in Bahrain. The study used the financial ratio for the period of 2005 - 2015. The study found that there was a differences between the performance before and after the oil price crisis.

Kaleem (2000) compared the performance of Islamic banks and conventional banks after crisis using financial ratio. The study found that Islamic banks is more crises-proofed in terms of its asset compared to conventional system.

Fannywaty and Daryanto (2019) measured the financial performance of non-stated owned banks in Indonesia. The method used risk-based bank rating for the period of $2014-2018$. It found that majority of non-stated owned banks are in a good health.

\section{RESEARCH METHOD}

This exploration has considered the bank execution for the period running from 2014 to 2018 where the Indonesian's financial development is dormant during those periods, and Bank PT. Pan Indonesia Bank, Tbk (Panin) and PT. Bank Mega, Tbk (Mega) faces a few changes.

This exploration dissects the financial health and execution dependent on estimation institutionalized by the Indonesian Financial Service Authority (OJK) under circular letter No. 14/SEOJK.03/2017 and Bank Indonesia Circular Letter No.13/24/DPNP 2011. This exploration utilizes a quantitative technique. The data were collected from the yearly report of the banks, fiscal reports, diaries, and articles. Execution examination is utilizing the Risk-Based Bank Rating (RBBR) model. The classifications utilized in the assessment procedure are Risk profile, Earnings, and Capital as appeared in Figure 1.

The Risk-based bank rating technique is the strategy used to quantify the bank's wellbeing. 
Following PBI Regulation 13/1/PBI/2011, the CAMELS technique is never again used to gauge the bank's wellbeing, and the new strategy, which is the Risk-Based Bank Rating strategy, was acquainted with survey the bank's wellbeing. As indicated by PBI Regulation No. 13/1/PBI/2011, banks are required to survey the adequacy of banks utilizing a hazard approach (Risk-Based Bank Rating). The viewpoints estimated incorporate risk profile, great corporate administration, income, and capital. Figure 1 shows the applied system utilized right now.

\section{Risk Profile}

Based on Indonesian Financial Service Authority Regulation No. 14/SEOJK.03/2017, the risk profile is the fundamental estimation of the bank on the grounds that the bank's exercises will in general represent a risk. The assessment comprises of eight sorts of risks, which are credit risk, market risk, liquidity risk, operational risk, legal risk, reputation risk, strategic risk, and compliance risk. This examination estimates risk profile utilizing the Non-Performing Loan (NPL) proportion for credit risk and Loan to Deposit Ratio (LDR) proportion for liquidity risk, which can be classifications as the huge risk profile as depicted in Table 1.

Table 1. Risk Profile Calculation

\begin{tabular}{cc}
\hline Risk Based Bank Rating & Ratio \\
\hline \multirow{2}{*}{ Risk Profile } & Non-Performing Loan \\
\cline { 2 - 2 } & Loan Deposit Ratio \\
\hline
\end{tabular}

Source: BI Circular Letter No. 13/24/DPNP/2011

\section{Non-Performing Loan (NPL)}

Credit risk is the risk of financial loss, should any of the bank customers, clients or market counterparties fail to fulfill their contractual obligations to the bank under agreements having been agreed (Bank Indonesia Regulation No. 13/23/PBI/2011). Credit risk arises mainly from loans. This study measures credit risk using

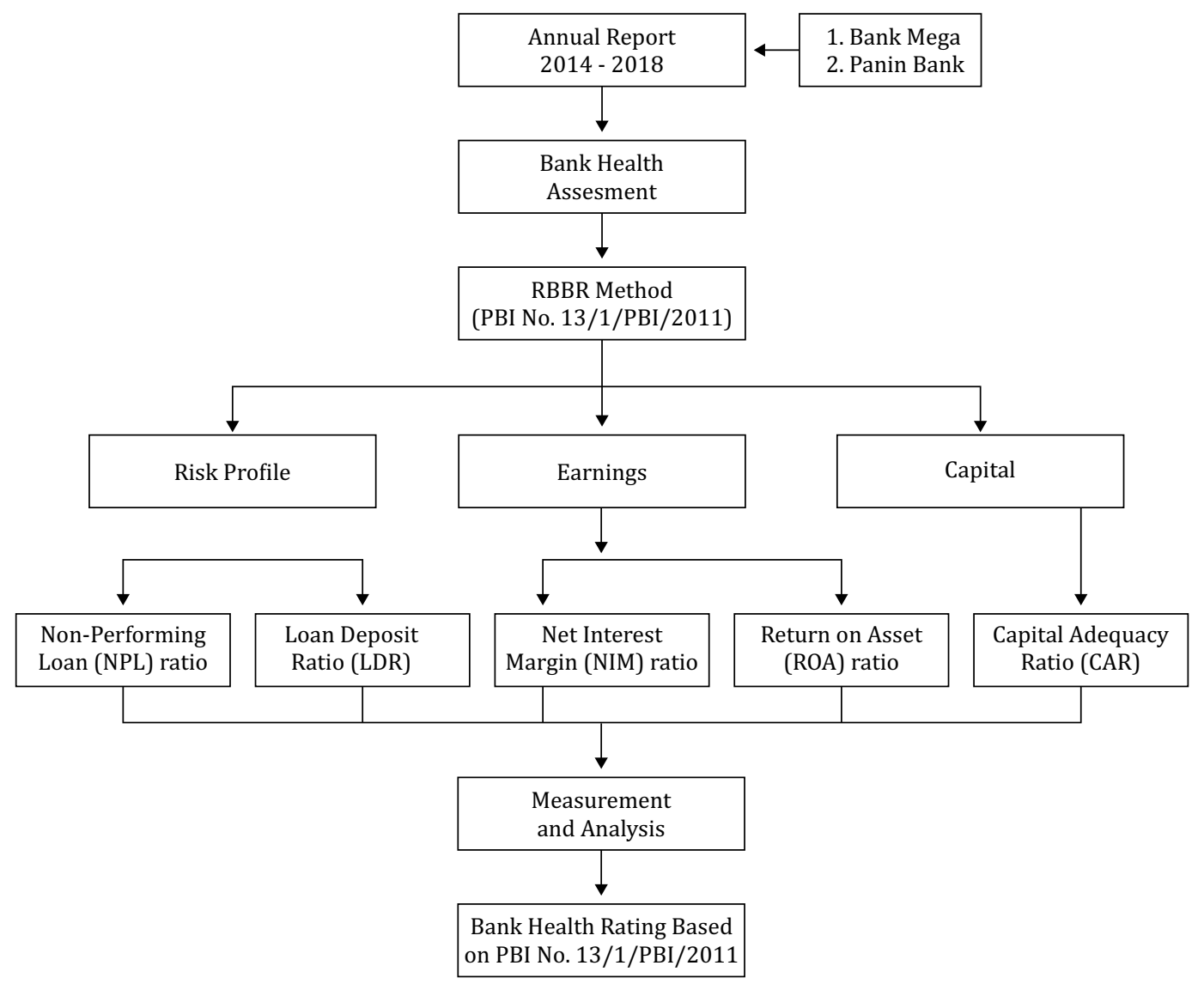


a ratio of Non-performing loans (NPL) based on Leaflet of Bank Indonesia No. 13/24/DPNP dated 25 October 2011. A non-performing loan (NPL) is the amount of lend money which the creditors have not made their payments schedule time (Investopedia, Nonperforming Loan - NPL, 2019). Non-performing loans classified as substandard, doubtful, and loss. Non-performing loan ratio is a comparison between non-performing loans and total loans. The smaller the NPL ratio, the smaller the credit risk borne by the bank. The higher the NPL ratio, the greater the potential number of uncollected loans, and the resulting decline in bank profitability. Based on Circular Letter of Bank Indonesia No. 13/30/DPNP dated 16 December 2011, the maximum non-performing loan ratio for a bank is $5 \%$ from the total loans given.

Table 2. Non-Performing Loan Parameter Criteria

\begin{tabular}{ccc}
\hline Rank & Criteria & Criteria \\
\hline 1 & $\mathrm{NPL}<2 \%$ & Very Healthy \\
\hline 2 & $2 \%<=\mathrm{NPL}<5 \%$ & Healthy \\
\hline 3 & $5 \%<=\mathrm{NPL}<8 \%$ & Quite Healthy \\
\hline 4 & $8 \%<=\mathrm{NPL}<12 \%$ & Less Healthy \\
\hline 5 & $\mathrm{NPL}>=12 \%$ & Unhealthy \\
\hline
\end{tabular}

Source: BI Circular Letter No. 13/24/DPNP/2011)

NPL formula:

$$
N P L=\frac{\text { Total Non Performing Loan }}{\text { Total Loan }}
$$

\section{Loan to Deposit Ratio (LDR)}

Liquidity risk is the risk that the bank can't meet their installment commitments as they fall due, including the withdrawal of client stores. Liquidity mirrors the bank's capacity to satisfy store withdrawals and different liabilities (Permatasari and Sawitri, 2018). A bank is said of having satisfactory liquidity potential when the bank can acquire the essential assets rapidly and at a sensible expense (Greuning and Iqbal, 2011: 143). This examination utilizes a Loan to Deposit Ratio (LDR) to quantify liquidity risk. LDR demonstrates the bank's capacity to repay the withdrawal of assets by investors to depending on credits as a liquidity source (Permatasari and Sawitri, 2018). LDR proportion is a correlation between absolute credits and outsider assets for a similar period. On the off chance that the proportion is excessively high, it implies that the bank might not have enough liquidity to cover any unpredicted store necessities. On the off chance that the proportion is excessively low, the bank may not be gaining as much as it could be. (Investopedia, 2019)

Table 3. Loan to Deposit Ratio Parameter Criteria

\begin{tabular}{ccc}
\hline Rank & Criteria & Criteria \\
\hline 1 & NPL $<=75 \%$ & Very Healthy \\
\hline 2 & $75 \%<$ LDR $<=85 \%$ & Healthy \\
\hline 3 & $85 \%<$ LDR $<=100 \%$ & Quite Healthy \\
\hline 4 & $100 \%<$ LDR $<=120 \%$ & Less Healthy \\
\hline 5 & LDR $>120 \%$ & Unhealthy \\
\hline
\end{tabular}

Source: BI Circular Letter No. 13/24/DPNP/2011

LDR formula:

$$
L D R=\frac{\text { Total Loans }}{\text { Third Party Funds }}
$$

\section{Good Corporate Governance (GCG)}

Great Corporate Governance is a structure that comprised of investors, partners, chiefs, and administrators to set and accomplishes corporate goals and screen execution (Zarkasyi, 2008: 35).

According to Bank Indonesia Regulation No. 4/8/PBI/2006 dated 30 January 2006 concerning Implementation of Good Corporate Governance for Commercial Banks, the usage of Good Corporate Governance in the financial business must be founded on five fundamental standards which are straightforwardness, responsibility, duty, freedom, and decency. Appraisal of Good Corporate Governance factors is evaluations of the bank the board quality on the execution of the Good Corporate Governance standards dependent on Bank Indonesia guideline and Indonesia Financial Service Authority's Circular Letter No.14/SE0JK.03/2017 by considering the attributes and multifaceted nature of bank business.

\section{Earnings}

In accordance to the Circular Letter of Bank Indonesia No. 13/24/DPNP 2011, appraisal of productivity factors incorporates assessing earnings performance, sources of profitability, 
the sustainability of profitability, and management of earnings. There are two stages for investigating banks' profit which are:

\section{Return on Asset (ROA)}

Return on Assets is a marker of how gainful an organization is comparative with its all resources. It shows how effective an organization's administration is at utilizing its advantages for creating income. (Investopedia, 2019)

Return on Assets proportion is determined by partitioning income before charge by all out resources. The high ROA implies the organization is proficient in using its advantages.

Table 4. Return on Assets Parameter Criteria

\begin{tabular}{ccc}
\hline Rank & Criteria & Criteria \\
\hline 1 & ROA $>1.5 \%$ & Very Healthy \\
\hline 2 & $1.25 \%<$ ROA $<=1.5 \%$ & Healthy \\
\hline 3 & $0.5 \%<$ ROA $<=1.25 \%$ & Quite Healthy \\
\hline 4 & $0 \%<$ ROA $<=0.05 \%$ & Less Healthy \\
\hline 5 & ROA $<=0 \%$ & Unhealthy \\
\hline
\end{tabular}

Source: BI Circular Letter No. 13/24/DPNP/2011)

ROA formula:

$$
R O A=\frac{\text { Earnings Before Taxes }}{\text { Total Asset }} \times 100 \%
$$

\section{Net Interest Margin (NIM)}

Net Interest Margin (NIM) is the capacity of banks to create net premium salary by putting beneficial resources possessed by organizations (Sari and Dahar, 2016).

Net Interest Income (NIM) is interest income deducted by interest expense borne by the bank. Productive assets are all assets that generate income in the form of lending, securities, investments, and other investments.

Table 5. Net Interest Margin Parameter Criteria

\begin{tabular}{ccc}
\hline Rank & Criteria & Criteria \\
\hline 1 & NIM $>3 \%$ & Very Healthy \\
\hline 2 & $2 \%<$ NIM $<=3 \%$ & Healthy \\
\hline 3 & $1.5 \%<$ NIM $<=2 \%$ & Quite Healthy \\
\hline 4 & $1 \%<$ NIM $<=1.5$ & Less Healthy \\
\hline 5 & NIM $<=1 \%$ & Unhealthy \\
\hline
\end{tabular}

Source: BI Circular Letter No. 13/24/DPNP/2011
NIM formula:

$$
N I M=\frac{\text { Net Interest Income }}{\text { Productive Asset }} \times 100 \%
$$

\section{Capital}

Capital is a part of the bank's financing sources, which can be utilized legitimately to raise another fund, bank capital, as an assurance to retain stuns from loss of business (Greuning and Iqbal, 2011: 213). As per Circular Letter of Indonesia Financial Service Authority No.14/SE0JK.03/2017, capital factor appraisal incorporates an assessment of capital sufficiency and ampleness of capital administration.

Capital appraisal depends on Capital Adequacy Ratio dictated by Bank Indonesia. The Capital Adequacy Ratio (CAR) is an estimation of a bank's cash-flow to recognize the bank's risk weighted credit exposures (Investopedia, 2019). CAR is utilized to suit losses that might have to be endured by the banks. The higher the CAR mirrors the bank's capacity to be better in managing the conceivable risk of loss.

Table 6. Capital Adequacy Ratio Parameter Criteria

\begin{tabular}{ccc}
\hline Rank & Criteria & Criteria \\
\hline 1 & CAR $>=12 \%$ & Very Healthy \\
\hline 2 & $9 \%<=$ CAR $<12 \%$ & Healthy \\
\hline 3 & $8 \%<=$ CAR $<9 \%$ & Quite Healthy \\
\hline 4 & $6 \%<=$ CAR $<8 \%$ & Less Healthy \\
\hline 5 & CAR $<=6 \%$ & Unhealthy \\
\hline
\end{tabular}

Source: BI Circular Letter No. 13/24/DPNP/2011

CAR formula:

$$
\text { CAR }=\frac{\text { Tier } 1 \text { Capital }+ \text { Tier } 2 \text { Capital }}{\text { Risk Weight Expsorues }}
$$

\section{RESULT AND DISCUSSION}

\section{Risk Profile}

Table 7. gives a result of a Non-Performing Loan (NPL) of Bank Mega and Bank Panin for the period of 2014 to 2018. During those years, Bank Panin and Bank Mega were categorized as healthy in accordance of Circular Letter of Bank Indonesia No. 13/24/DPNP 2011 standard with an average NPL ratio of $2.39 \%$ and $2.63 \%$, respectively which is above $2 \%$. 
Wiwiek Mardawiyah Daryanto / Comparison of Financial Performance Buku III Indonesian Banks Using Risk-Based Bank Rating (Rbbr) Method: Case Study of PT. Pan Indonesia Bank, Tbk (Panin) and

PT. Bank Mega, Tbk (Mega) / 37 - 45

Table 8. shows a Loan to Deposit Ratio (LDR) of Bank PT. Pan Indonesia Bank, Tbk (Panin) and PT. Bank Mega, Tbk (Mega) for the period of 2014 to 2018. From 2014 to 2018, Bank Mega positioned as the very healthy bank in term of LDR, contrary, Bank Panin demonstrated a quite healthy predicate with an average LDR of $93.81 \%$.

\section{Earnings Factor Performances}

Table 9. depicts a Return on Asset of Bank PT. Pan Indonesia Bank, Tbk (Panin) and PT. Bank Mega, Tbk (Mega) for the period of 2014 to 2018. The average ratio of ROA of Bank Mega and Bank Panin were indicated as very healthy predicate with a standard ratio above $1.5 \%$ as per Circular Letter of Bank Indonesia No.13/24/DPNP 2011.

Table 10. indicates Net Interest Margin Ratio of Bank PT. Pan Indonesia Bank, Tbk (Panin) and
PT. Bank Mega, Tbk (Mega) for the period of 2014 to 2018. During years of 2014 to 2018, Bank Mega and Bank Panin showed a very healthy performance. They were obtained a NIM of 5.86\% and $4.44 \%$ respectively, which are above $3 \%$ as per Circular Letter of Bank Indonesia No. 13/24/ DPNP 2011.

\section{Capital Factor Performances}

Table 11. demonstrates a Capital Adequacy Ratio of Bank PT. Pan Indonesia Bank, Tbk (Panin) and PT. Bank Mega, Tbk (Mega) for five years period from 2014 to 2018. In term of CAR, Bank Mega and Bank Panin were classified as very healthy predicate means that the average of the ratios was above the standard, which is $12 \%$ according to Circular Letter of Bank Indonesia No. 13/24/ DPNP 2011.

Table 7. Non-Performing Loan Ratio 2014 - 2018

\begin{tabular}{clrrrrrrc}
\hline Rank & Bank Name & $\mathbf{2 0 1 4}$ & $\mathbf{2 0 1 5}$ & $\mathbf{2 0 1 6}$ & $\mathbf{2 0 1 7}$ & $\mathbf{2 0 1 8}$ & Average & Category \\
\hline 1 & MEGA & $2.09 \%$ & $2.81 \%$ & $3.44 \%$ & $2.01 \%$ & $1.60 \%$ & $2.39 \%$ & Healthy \\
\hline 2 & PANIN & $2.01 \%$ & $2.44 \%$ & $2.81 \%$ & $2.84 \%$ & $3.04 \%$ & $2.63 \%$ & Healthy \\
\hline
\end{tabular}

Source: Annual Report MEGA and PANIN 2014 - 2018

Table 8. Loan to Deposit Ratio 2014 - 2018

\begin{tabular}{clccccccc}
\hline Rank & Bank Name & $\mathbf{2 0 1 4}$ & $\mathbf{2 0 1 5}$ & $\mathbf{2 0 1 6}$ & $\mathbf{2 0 1 7}$ & $\mathbf{2 0 1 8}$ & Average & Category \\
\hline 1 & MEGA & $65.85 \%$ & $65.05 \%$ & $55.35 \%$ & $56.47 \%$ & $67.23 \%$ & $61.99 \%$ & Very Healthy \\
\hline 2 & PANIN & $90.51 \%$ & $92.22 \%$ & $90.07 \%$ & $92.10 \%$ & $104.15 \%$ & $93.81 \%$ & Quite Healthy \\
\hline
\end{tabular}

Source: Annual Report MEGA and PANIN 2014 - 2018

Table 9. Return on Asset Ratio 2014 - 2018

\begin{tabular}{cllllllll}
\hline Rank & Bank Name & $\mathbf{2 0 1 4}$ & $\mathbf{2 0 1 5}$ & $\mathbf{2 0 1 6}$ & $\mathbf{2 0 1 7}$ & $\mathbf{2 0 1 8}$ & Average & Category \\
\hline 1 & MEGA & $1.16 \%$ & $1.97 \%$ & $2.36 \%$ & $2.24 \%$ & $2.47 \%$ & $2.04 \%$ & Very Healthy \\
\hline 2 & PANIN & $2.23 \%$ & $1.31 \%$ & $1.69 \%$ & $1.61 \%$ & $2.16 \%$ & $1.80 \%$ & Very Healthy \\
\hline
\end{tabular}

Source: Annual Report MEGA and PANIN 2014 - 2018

Table 10. Net Interest Margin Ratio 2014 - 2018

\begin{tabular}{clcccccccc}
\hline Rank & Bank Name & $\mathbf{2 0 1 4}$ & $\mathbf{2 0 1 5}$ & $\mathbf{2 0 1 6}$ & $\mathbf{2 0 1 7}$ & $\mathbf{2 0 1 8}$ & Average & Category \\
\hline 1 & MEGA & $5.27 \%$ & $6.04 \%$ & $7.01 \%$ & $5.80 \%$ & $5.19 \%$ & $5.86 \%$ & Very Healthy \\
\hline 2 & PANIN & $3.06 \%$ & $4.61 \%$ & $5.03 \%$ & $4.68 \%$ & $4.84 \%$ & $4.44 \%$ & Very Healthy \\
\hline
\end{tabular}

Source: Annual Report MEGA and PANIN 2014 - 2018

Table 11. Capital Adequacy Ratio 2014 - 2018

\begin{tabular}{clcccccccc}
\hline Rank & Bank Name & $\mathbf{2 0 1 4}$ & $\mathbf{2 0 1 5}$ & $\mathbf{2 0 1 6}$ & $\mathbf{2 0 1 7}$ & $\mathbf{2 0 1 8}$ & Average & Category \\
\hline 1 & MEGA & $15.23 \%$ & $22.85 \%$ & $26.21 \%$ & $24.11 \%$ & $22.79 \%$ & $22.24 \%$ & Very Healthy \\
\hline 2 & PANIN & $17.30 \%$ & $20.13 \%$ & $20.49 \%$ & $21.99 \%$ & $23.33 \%$ & $20.65 \%$ & Very Healthy \\
\hline
\end{tabular}

Source: Annual Report MEGA and PANIN 2014 - 2018 


\section{CONCLUSION AND RECOMMENDATION}

The aim of this study is to provide a comparison of the financial condition and overall performance of the two public listed non-stated-owned banks with core capital of IDR. 5 trillion to less than IDR.30 Trillion (BUKU III) within the period of 2014-2018. Financial conditions and overall performance of Bank PT. Pan Indonesia Bank, Tbk (Panin) and PT. Bank Mega, Tbk (Mega) is measured and analyzed by using the Risk-Based Bank Rating (RBBR) method according to Circular Letter of Bank Indonesia No. 13/24/ DPNP 2011. The finding shows that both banks had performed well in term of risk profile from credit risk performance measurement, liquidity risk performance measurement, earnings factor, and capital factor. However, Bank Mega had better performance in terms of Loan to Deposit Ratio (LDR). Therefore, the first rating rank was Bank Mega compared to Bank Panin. This study give contribution to the body knowledge of financial literature. The result can be used as a reference to the student about risk rating of banking industry and further future research. In addition, this study has managerial implication where it give a strong insight for managers in bank industry about the financial health performance that will help them make a better decision with the purpose to increase the market share and the profitability.

\section{REFERE N C ES}

Adesina, K. S. (2012). A Comparative Performance Evaluation of the Nigerian Banking Sector in the Post -2005 Consolidation: Through the CAMEL Rating System. International Journal of Business and Social Science, 3(12): 1-6.

Bank Indonesia. (2006). Pelaksanaan Good Corporate Governance bagi Bank Umum (No. 8/4/PBI). Jakarta.

Bank Indonesia. (2009). Perubahan atas Peraturan Bank Indonesia Nomor 5/8/PBI/2003 Tentang Penerapan Manajemen Risiko Bagi Bank Umum (No. 11/25/PBI). Surat Edaran kepada Semua Bank Umum di Indonesia. Jakarta.

Bank Indonesia. (2011). Prihal Laporan Keuangan Publikasi Triwulan dan Bulanan Bank Umum Serta Laporan Tertentu yang Disampaikan kepada Bank Indonesia (No. 13/30/DPNP). Surat Edaran kepada Semua Bank Umum di Indonesia. Jakarta.

Bank Indonesia. (2011). Sistem Penilaian Tingkat Kesehatan Bank Umum (No. 13/24/DPNP). Surat Edaran kepada Semua Bank Umum yang Melaksanakan Kegiatan Usaha Secara Konvensional di Indonesia. Jakarta.

Bank Indonesia. (2012). Kegiatan Usaha dan Jaringan Kantor Berdasarkan Modal Inti Bank (No. 14/26/ PBI). Surat Edaran kepada Semua Bank Umum di Indonesia. Jakarta.

Biro Pusat Statistik. (2019). Pertumbuhan Ekonomi Indonesia 2014-2018. Jakarta.

Budisantoso, T., \& Sigit, T. (2006). Bank dan Lembaga Keuangan Lain. $2^{\text {nd }}$ ed., Jakarta: Salemba Empat. Chitya, C. (2015). Pengaruh NPL, LDR, CAR Terhadap Profitabilitas Bank Umum Swasta Nasional Devisa. Science and Management Research, 4(4): 1-16.

Daryanto, W. M., Nurfadilah, D. (2018). Financial performance analysis before and after the decline in oil production: Case study in Indonesian oil and gas industry. International Journal of Engineering \& Technology, 7(3.21),10-15.

Investopedia.com. (2019). Non-Performing Loan Definition. www.investopedia.com. 28 September 2019. Otoritas Jasa Keuangan. (2017). Penilaian Tingkat Kesehatan Bank Umum (No 14/SE0JK.03/2017). Jakarta. Pinto, P., Hawaldar, I. T., Rahiman, H. U., Rajesha, T. M., PT. Bank Mega, Tbk. 2018. Annual Report 2018. Jakarta 
Wiwiek Mardawiyah Daryanto / Comparison of Financial Performance Buku III Indonesian Banks Using Risk-Based Bank Rating (Rbbr) Method: Case Study of PT. Pan Indonesia Bank, Tbk (Panin) and

PT. Bank Mega, Tbk (Mega) / 37 - 45

PT. Bank Mega, Tbk. 2016. Annual Report 2016. Jakarta.

PT. Pan Indonesia Bank, Tbk. 2018. Annual Report 2018. Jakarta.

PT. Pan Indonesia Bank, Tbk. 2016. Annual Report 2016. Jakarta.

Suryani, Y., \& Azwansyah, H. (2017). Analisis Pengaruh Rasio-Rasio Risk Based Rating terhadap Pertumbuhan Laba pada Perusahaan Perbankan yang Terdaftar di BEI. Kitabah, 1(1): 48.

Undang - Undang Republik Indonesia No. 10 (1998), Perihal Perubahan atas Undang - Undang No. 7 Tahun 1992 tentang Perbankan.

Zarkasyi, M. W. (2008). Good Corporate Governance Pada Badan Usaha Manufaktur, Perbankan, dan Jasa Keuangan Lainnya. Bandung: Alfabeta. 